Copyright (C) 2016 by Academic Publishing House Researcher

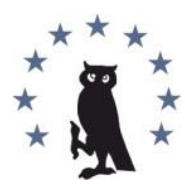

Published in the Russian Federation

European Researcher

Has been issued since 2010.

ISSN 2219-8229

E-ISSN 2224-0136

Vol. 104, Is. 3, pp. 168-177, 2016

DOI: 10.13187/er.2016.104.168

www.erjournal.ru

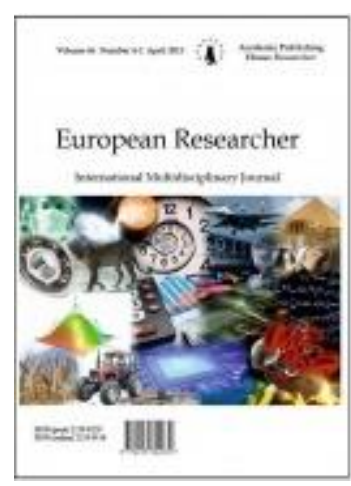

UDC 33

\title{
The Comparative Analysis of Investment Activities on the Oil Refining Enterprises in the Russian Federation (on the example of JSC "LUKOIL" and JSC "GAZPROM-Refinery")
}

${ }^{1}$ O.V. Trofimov

${ }^{2}$ D.S. Novikova

3 A.D. Novikova

1-3 Lobachevsky State University of Nizhni Novgorod, Russian Federation

${ }^{1}$ Doctor of Economic Sciences, Professor

${ }^{2}$ Assistant

${ }^{3}$ Laboratory researcher

\begin{abstract}
This article is devoted to research of specific features of investment management on the oil refining enterprise in the Russian Federation. The aim of this article is to give a comparative analysis of investment activities on the oil refineries. To achieve this goal the article will be addressed the following tasks:

1. Studying the academic definition of the term investment, then, on the basis of the studied material and the comparative analysis, offer the own definition of this term;

2. Giving the examples of investment activities of several oil refineries, namely, PJSC "LUKOIL" and PJSC "GAZPROM oil refinery";

3. Analyzing the statistics of refineries, and justifying the investment on the oil refinery.

Keywords: investments, investment activity, investment activity management on the oil refining enterprise.

\section{Введение}

Экономика каждой страны базируется на различных отраслях (промышленность, сельское хозяйство, лесное хозяйство и т.д.). Ведущей отраслью в РФ является промышленность [1]. Непосредственно топливная промышленность включает в себя нефтяную, газовую и угольную отрасли.

В отличие от большинства топливно-энергетических комплексов, российский ТЭК не только снабжает страну топливом и электроэнергией, но и является основой национальной экономики, обеспечивая большую часть валютных поступлений [2]. Так, по данным 2013 года, ТЭК России обеспечил 30 \% от национального ВВП, 50 \% налоговых доходов бюджета, занял первое место по экспорту - 70 \% от его общего объема.

В состав нефтяной промышленности России входят нефтедобывающие предприятия, нефтеперерабатывающие заводы (НПЗ), предприятия по транспортировке и сбыту нефти и нефтепродуктов. В настоящее время в отрасли действуют 28 крупных нефтеперерабатывающих заводов (мощностью от одного миллиона тонн в год), мини-НПЗ и заводы по
\end{abstract}


производству масел [3]. Протяженность магистральных нефтепроводов составляет около 50 тысяч километров, нефтепродуктопроводов - 19,3 тысячи километров. Структуру нефтяной отрасли составляют десять крупных вертикально интегрированных нефтяных компаний. Наиболее мощные - «Роснефть», «ЛУКОЙЛ», «Сургутнефтегаз», «ТНК-ВР» и «Газпром нефть». Транспортировку нефти и нефтепродуктов осуществляют предприятия акционерных компаний «Транснефть» и «Транснефтепродукт» [4]. Газовая промышленность России включает в себя предприятия, ведущие геологоразведочные работы, бурение разведочных и эксплуатационных скважин, добычу, транспортировку и хранение газа. Единая система газоснабжения имеет более 162 тысяч километров магистральных газопроводов и отводов, 215 линейных компрессорных станций с общей мощностью газоперекачивающих агрегатов в 42,1 тысячи МВ тонн, шесть комплексов по переработке газа и газового конденсата, 25 объектов подземного хранения газа. Природный и попутный нефтяной газ является в настоящее время основным источником обеспечения внутренних потребностей страны в первичных энергоресурсах $[5,6]$. Нефтяная промышленность - отрасль экономики, занимающаяся добычей, переработкой, транспортировкой, складированием и продажей природного полезного ископаемогонефти и сопутствующих нефтепродуктов. На 2014 год отраслевая структура добычи нефти выглядела следующим образом.

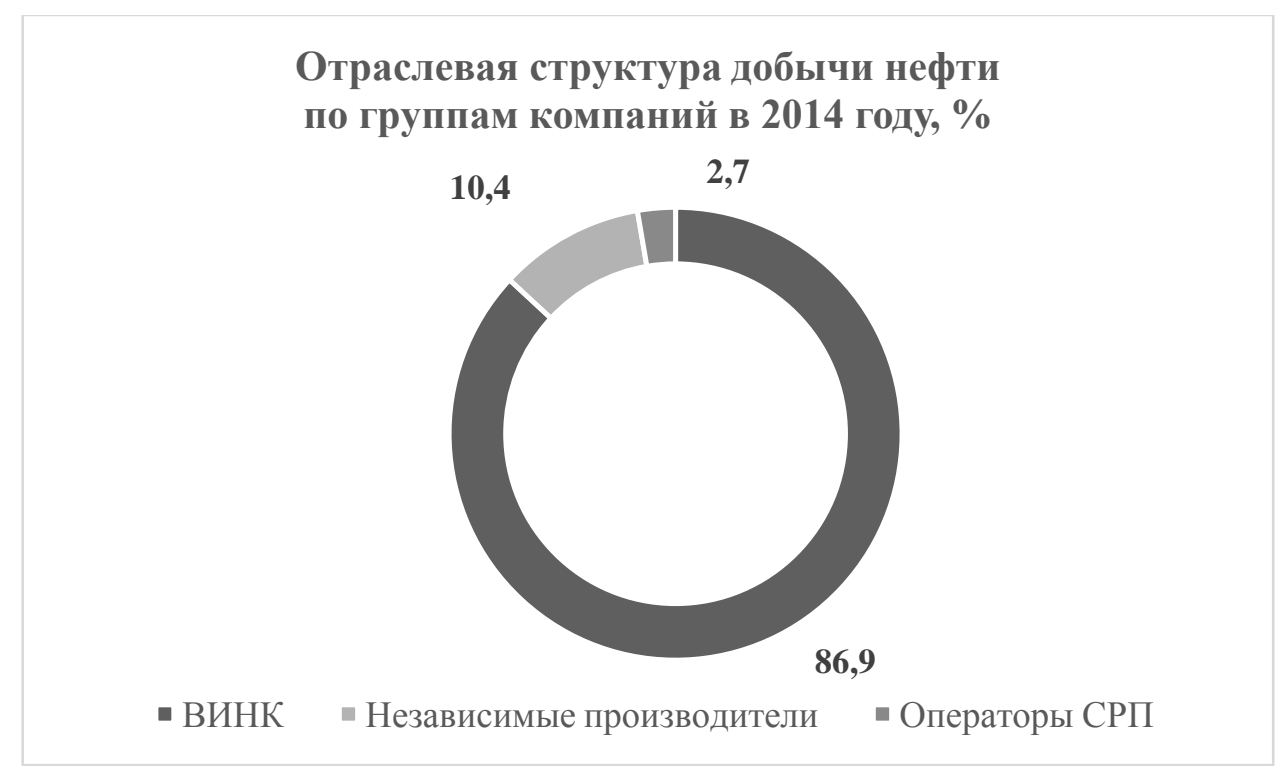

Puc. 1. Отраслевая структура добычи нефти по группам компаний в 2014 году Источник: данные Министерства энергетики Российской Федерации]

Активное использование всевозможных средств в целях поиска и разведывания местонахождения нефти, создание нового, качественного оборудования для добычи нефти, и, следовательно, увеличение качества и глубины переработки нефти, - является одной из основных задач удержания лидирующих позиций нефтяной промышленности в РФ [7]. В этой связи на нефтеперерабатывающем предприятии возникает проблема нехватки внутренних ресурсов для достижения поставленных целей и реализации вытекающих задач. Одним из возможных путей решения является создание благоприятного инвестиционного климата и, как результат, привлечение внешних инвестиций.

\section{Основное содержание}

В начале данного исследования необходимо изучить академическое определение термина инвестиции и на основе изученного материала и проведенного сравнительного анализа (таблица 1), предложить своё определение данного термина [8, 9]. Как в отечественной, так и в зарубежной литературе, существует многообразие трактовок понятия инвестиций, которые будут рассмотрены ниже в таблице 1. 
Сравнительный анализ определения инвестиции

\begin{tabular}{|c|c|c|c|}
\hline Автор & Определение & $\begin{array}{c}\text { Схожие черты с } \\
\text { другими } \\
\text { определениями }\end{array}$ & $\begin{array}{l}\text { Различия, } \\
\text { авторские } \\
\text { допущения } \\
\end{array}$ \\
\hline 1. И.А. Бланк & 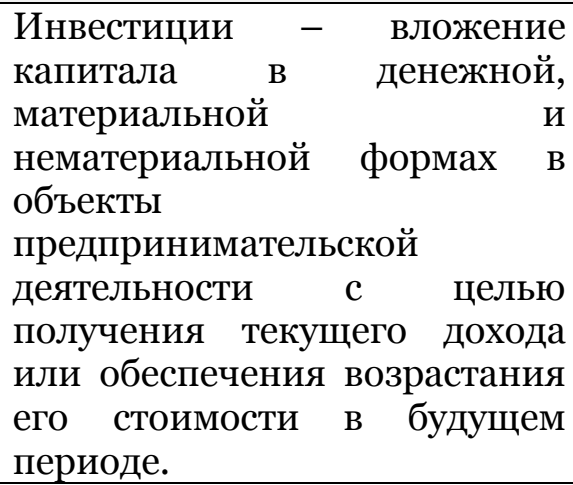 & $\begin{array}{l}\rightarrow \quad \text { вложение } \\
\text { капитала } \\
\rightarrow \quad \text { денежная, } \\
\text { материальная } \\
\text { нематериальная } \\
\text { форма вложения } \\
\rightarrow \quad \text { цель- } \\
\text { получение дохода }\end{array}$ & - \\
\hline 2. Я.С. Меркулов & $\begin{array}{l}\text { Tермин «инвестиции» } \\
\text { происходит от латинского } \\
\text { слова investire - облачать. C } \\
\text { финансовой и экономической } \\
\text { точек зрения инвестирование } \\
\text { может быть определено как } \\
\text { долгосрочное } \\
\text { экономических ресурсов с } \\
\text { целью создания и получения } \\
\text { чистой прибыли в будущем, } \\
\text { превышающей } \\
\text { начальную } \\
\text { инвестиций. }\end{array}$ & $\begin{array}{l}\rightarrow \quad \text { Цель- } \\
\text { создание } \\
\text { получение чи чистой } \\
\text { прибыли } \\
\rightarrow \quad \text { Вложение } \\
\text { экономических } \\
\text { ресурсов }\end{array}$ & - \\
\hline 3. В.Г. Золотогоров & 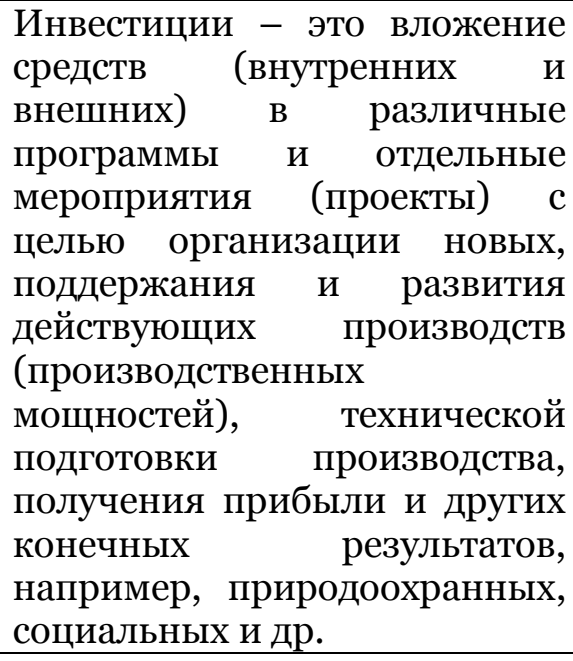 & $\begin{array}{l}\rightarrow \quad \text { Вложение } \\
\text { внутренних } \\
\text { внешних средств } \\
\rightarrow \quad \text { Цель- } \\
\text { получение } \\
\text { прибыли }\end{array}$ & $\begin{array}{l}\rightarrow \quad \text { Вложе } \\
\text { ние средств в } \\
\text { программы с } \\
\text { целью } \\
\text { организации } \\
\text { новых } \\
\rightarrow \quad \text { Получе } \\
\text { ние } \\
\text { природоохран } \\
\text { ительных, } \\
\text { социальных } \\
\text { результатов }\end{array}$ \\
\hline $\begin{array}{l}\text { 4. В. Сергеев и } \\
\text { И.И. Веретенников } \\
\text { a }\end{array}$ & 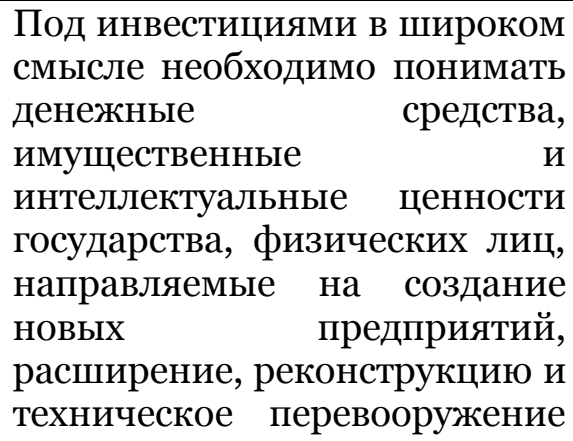 & $\begin{array}{l}\rightarrow \quad \text { Денежные } \\
\text { средства } \\
\rightarrow \quad \text { Цель- } \\
\text { получение } \\
\text { прибыли }\end{array}$ & $\begin{array}{l}\rightarrow \quad \text { Имуще } \\
\text { ственные и } \\
\text { интеллектуал } \\
\text { ьные } \\
\text { ценности } \\
\text { государства, } \\
\text { физических } \\
\text { лиц } \\
\rightarrow \quad \text { Вложе } \\
\text { ние на }\end{array}$ \\
\hline
\end{tabular}




\begin{tabular}{|c|c|c|c|}
\hline & $\begin{array}{l}\text { действующих, приобретение } \\
\text { недвижимости, } \\
\text { облигаций и других ценный } \\
\text { бумаг и активов с целью } \\
\text { получения прибыли (и) или } \\
\text { иного } \\
\text { эффекта. }\end{array}$ & & $\begin{array}{l}\text { создание } \\
\text { акций, } \\
\text { облигаций, } \\
\text { других } \\
\text { ценных бумаг }\end{array}$ \\
\hline $\begin{array}{l}\text { 5. М.Ю. Маковецки } \\
\text { й }\end{array}$ & $\begin{array}{l}\text { Инвестиции - это вложения } \\
\text { сбережений всех участников } \\
\text { экономической системы как в } \\
\text { объекты } \\
\text { предпринимательской } \\
\text { других видов деятельности, } \\
\text { так и в ценные бумаги и иные } \\
\text { активы с целью извлечения } \\
\text { дохода (прибыли) или } \\
\text { достижения положительного } \\
\text { (социального) эффекта. }\end{array}$ & $\begin{array}{l}\rightarrow \quad \text { Цель- } \\
\text { получение } \\
\text { прибыли }\end{array}$ & $\begin{array}{l}\rightarrow \quad \text { Вложе } \\
\text { ние } \\
\text { сбережений } \\
\text { всех } \\
\text { участников } \\
\text { экономическо } \\
\text { й системы }\end{array}$ \\
\hline $\begin{array}{l}\text { 6. Г.П. } \\
\text { Подшиваленко }\end{array}$ & 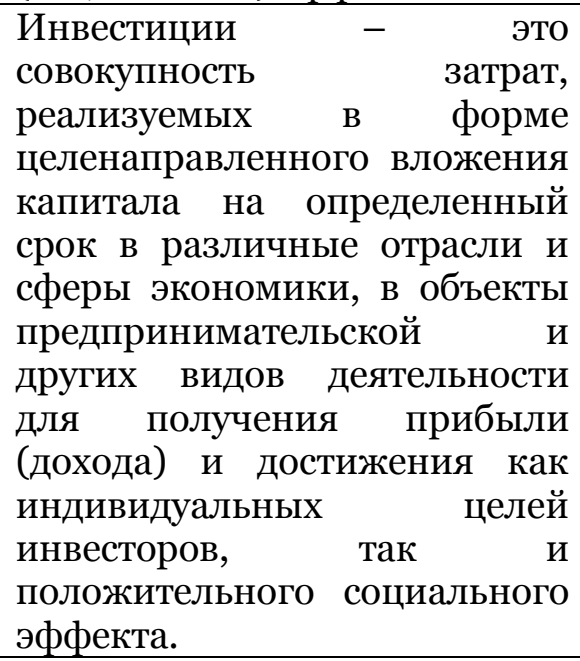 & $\begin{array}{l}\rightarrow \quad \text { Целенаправ } \\
\text { ленное вложение } \\
\text { капитала } \\
\rightarrow \quad \text { Цель- } \\
\text { получение } \\
\text { прибыли }\end{array}$ & - \\
\hline 7. П. Самуэльсон & 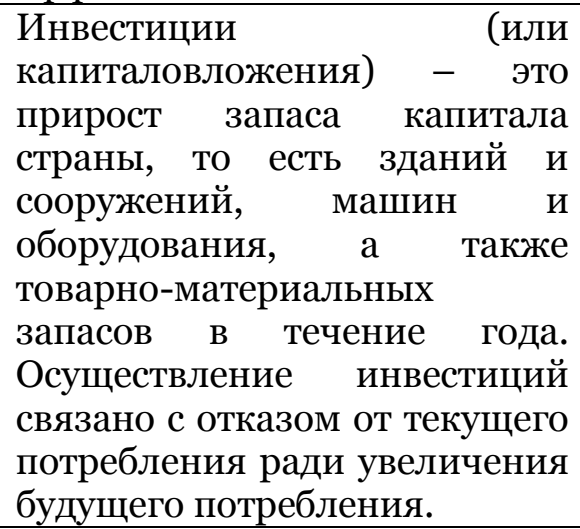 & $\begin{array}{l}\rightarrow \quad \text { Положитель } \\
\text { ный } \quad \text { социальный } \\
\text { эффект }\end{array}$ & $\begin{array}{ll}\rightarrow & \text { Приро } \\
\text { ст } & \text { запасов } \\
\text { капитала } \\
\text { страны }\end{array}$ \\
\hline $\begin{array}{l}\text { 8. Л.ДЖ. Гитман и } \\
\text { М.Д. Джонк }\end{array}$ & 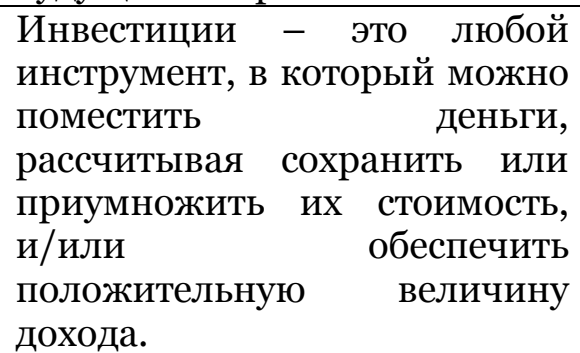 & $\begin{array}{l}\rightarrow \quad \text { Цель- } \\
\text { получение } \\
\text { прибыли }\end{array}$ & $\begin{array}{l}\rightarrow \quad \text { Инстру } \\
\text { мент, } \\
\text { который } \\
\text { можно } \\
\text { вложить } \\
\text { деньги }\end{array}$ \\
\hline
\end{tabular}

Источник: составлено автором 
Таким образом, учитывая многообразие авторских определений и обобщая мнения различных авторов, в целях данного исследования наиболее ёмкой и целесообразной трактовкой понятия инвестиции, по мнению авторов статьи, может служить следующая: инвестиции - это совокупность затрат, реализованных в форме целенаправленного вложении капитала на определённый срок в различные отрасли и сферы экономики, в объекты предпринимательской и других видов деятельности для получения прибыли и достижения как индивидуальных целей, так и положительного социального эффекта. В свою очередь, в узком определении инвестиционная деятельность представляет собой процесс преобразования инвестиционных ресурсов во вложения [10]. В широком определении инвестиционная деятельность - это деятельность, связанная с вложением средств в объекты инвестирования в целях приращения капитальной стоимости [11]. С данной трактовкой термина инвестиционная деятельность допускается:

- преобразование инвестиционных ресурсов в инвестиционные вложения, т.е. процесс трансформации ресурсов в конкретные объекты инвестиционной деятельности;

- превращение вложенных средств в прирост капитальной стоимости, окупаемость осуществлённых затрат и получение дохода в результате использования инвестиций.

Инвестиционная деятельность, с одной стороны, связана с вложением средств, с другой - целесообразность этих вложений определяется отдачей. Без получения дохода отсутствует мотивация инвестиционной деятельности [12].

Управление инвестиционной деятельностью нефтяной компании включает нескольких фаз:

1. сбор исходной информации от дочерних предприятий в виде инвестиционных заявок, содержащих формализованное технико-экономическое обоснование инвестиционных проектов, определение сценарных условий;

2. оценка показателей эффективности инвестиционных проектов;

3. оптимизация инвестиционного портфеля;

4. мониторинг и сопровождение инвестиционных проектов.

Перед началом любой инвестиционной деятельности следует проанализировать инвестиционную привлекательность нефтяной компании, отталкиваясь от динамики показателей фирмы и стадии её жизненного цикла [13].

\section{Оценка инвестиционной привлекательности компании от её стадии жизненного цикла}

Таблица 2

\begin{tabular}{|c|c|c|}
\hline $\begin{array}{c}\text { Стадия } \\
\text { жизненного } \\
\text { цикла } \\
\text { компании }\end{array}$ & $\begin{array}{l}\text { Динамика } \\
\text { показателей }\end{array}$ & $\begin{array}{c}\text { Инвестиционная привлекательность } \\
\text { компании }\end{array}$ \\
\hline $\begin{array}{l}\text { «рождение», } \\
\text { «детство», } \\
\text { «юность», } \\
\text { «ранняя } \\
\text { зрелость» }\end{array}$ & $\begin{array}{l}\text { Прирост показателей. } \\
\text { На стадиях «юность» } \\
\text { и «ранняя зрелость»- } \\
\text { наиболее высокие } \\
\text { темпы прироста }\end{array}$ & $\begin{array}{l}\text { Компания находится в процессе роста (развития), } \\
\text { инвестиционная привлекательность самая } \\
\text { высокая }\end{array}$ \\
\hline $\begin{array}{l}\text { «окончательная } \\
\text { зрелость» }\end{array}$ & $\begin{array}{l}\text { Стабилизация } \\
\text { большинства } \\
\text { показателей }\end{array}$ & $\begin{array}{l}\text { Инвестирование целесообразно, если продукция } \\
\text { компании имеет достаточно высокие маркетинговые } \\
\text { перспективы, а объем инвестиций в техническое } \\
\text { перевооружение относительно небольшой и вложенные } \\
\text { средства могут окупиться в кратчайшие сроки }\end{array}$ \\
\hline «старение» & $\begin{array}{l}\text { Снижение } \\
\text { показателей }\end{array}$ & $\begin{array}{l}\text { Инвестирование, как правило, нецелесообразно. } \\
\text { Исключение: обширная диверсификация выпускаемой } \\
\text { продукции (товаров, услуг), т.е. определенное } \\
\text { перепрофилирование предприятия. В этом случае } \\
\text { возможна определенная экономия инвестиционных } \\
\text { ресурсов в сравнении с новым строительством }\end{array}$ \\
\hline
\end{tabular}

Источник: составлено автором. 
Для наглядности рассмотрим инвестиционную деятельность нефтеперерабатывающих предприятий - ПАО «Лукойл» и ПАО «Газпром нефть».

Таблица 3

Инвестиционная деятельность на НПП ПАО «Лукойл» и ПАО «Газпром»

\begin{tabular}{|c|c|c|c|}
\hline $\begin{array}{c}\text { Нефтеперераб } \\
\text { атывающее } \\
\text { предприятие }\end{array}$ & $\begin{array}{c}\text { Основные характерные } \\
\text { черты }\end{array}$ & $\begin{array}{c}\text { Общие черты } \\
\text { ведения } \\
\text { инвестиционно } \\
\text { й деятельности }\end{array}$ & $\begin{array}{c}\text { Различия в } \\
\text { вопросе } \\
\text { ведения } \\
\text { инвестиционно } \\
\text { й деятельности } \\
\end{array}$ \\
\hline ПАО «Лукойл» & $\begin{array}{l}\rightarrow \quad \text { одна из крупнейших } \\
\text { вертикально интегрированных } \\
\text { нефтегазовых компаний в мире, } \\
\text { на долю которой на 2014год } \\
\text { приходится более } 2 \text { \% мировой } \\
\text { добычи нефти и около } 1 \% \\
\text { доказанных запасов } \\
\text { углеводородов } \\
\rightarrow \quad \text { Более } 110 \text { тысяч человек } \\
\text { объединяют свои усилия и талант, } \\
\text { чтобы обеспечить компании } \\
\text { передовые позиции на рынке. } \\
\rightarrow \quad \text { Компания полностью } \\
\text { контролирует всю } \\
\text { производственную цепочку - от } \\
\text { добычи нефти и газа до сбыта } \\
\text { нефтепродуктов } \\
\rightarrow \quad \text { Более } 2 \text { \% общемировой } \\
\text { добычи нефти } \\
\rightarrow \quad \text { Около } 1 \text { \% мировых } \\
\text { доказанных запасов нефти } \\
\rightarrow \quad 16,4 \% \text { общероссийской } \\
\text { добычи нефти и } 15,7 \% \\
\text { общероссийской переработки } \\
\text { нефти } \\
\rightarrow \quad \text { Крупнейшая российская } \\
\text { негосударственная компания } \\
\text { (Fогbеs) с выручкой по итогам } \\
2014 \text { года более } 144 \text { млрд. долл. } \\
\text { и чистой прибылью около } 5 \text { млрд } \\
\text { долл. }\end{array}$ & 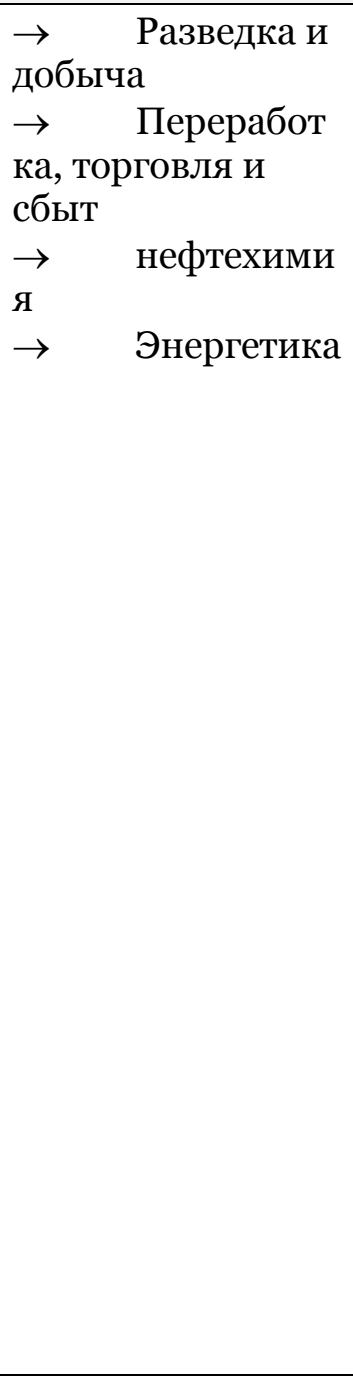 & $\begin{array}{l}\rightarrow \quad \text { Прочие } \\
\text { (укрепление } \\
\text { сырьевой базы, } \\
\text { модернизация } \\
\text { перерабатывающ } \\
\text { их мощностей) }\end{array}$ \\
\hline ПАО «Газпром» & $\begin{array}{l}\rightarrow \quad \text { Вертикально- } \\
\text { интегрированная нефтяная } \\
\text { компания, основные виды } \\
\text { деятельности которой - разведка } \\
\text { и разработка месторождений } \\
\text { нефти и газа, нефтепереработка, а } \\
\text { также производство и сбыт } \\
\text { нефтепродуктов } \\
\rightarrow \quad \text { Постоянное движение } \\
\text { вперед - важная отличительная } \\
\text { черта Газпрома. } \\
\rightarrow \quad \text { Газпром продолжает } \\
\text { масштабную работу по }\end{array}$ & $\begin{array}{l}\rightarrow \quad \text { Разведка и } \\
\text { добыча } \\
\rightarrow \quad \text { Нефтехими } \\
\text { я } \\
\rightarrow \quad \text { Газификац } \\
\text { ия и } \\
\text { газораспределени } \\
\text { е, развитие } \\
\text { рынков } \\
\text { газомоторного } \\
\text { топлива } \\
\rightarrow \quad \text { Маркетинг }\end{array}$ & $\begin{array}{l}\rightarrow \quad \text { Транспорт } \\
\text { ировка и } \\
\text { подземное } \\
\text { хранение } \\
\rightarrow \quad \text { Электроэне } \\
\text { ргетика } \\
\rightarrow \quad \text { Переработ } \\
\text { ка } \\
\text { углеводородного } \\
\text { сырья, газохимия } \\
\rightarrow \quad \text { формирова } \\
\text { ние новых }\end{array}$ \\
\hline
\end{tabular}




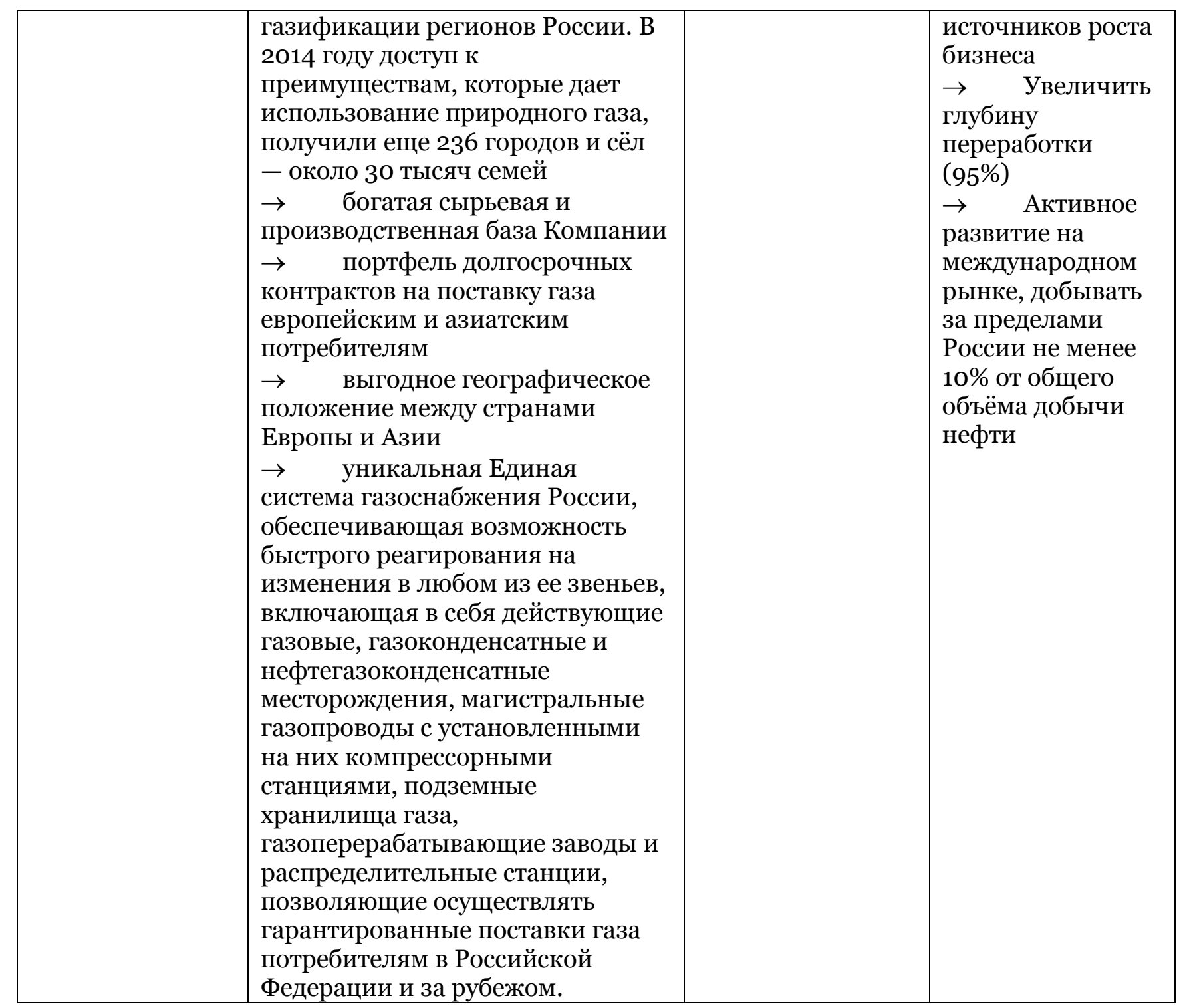

Источник: составлено автором.

Таким образом, проанализировав программу нефтеперерабатывающих предприятий, мы приходим к следующим заключениям:

$\rightarrow \quad$ Целью нефтеперерабатывающего предприятия является расширение добычи нефти как в России, так и за рубежом

$\rightarrow \quad$ Нефтеперерабатывающее предприятие заинтересовано в привлечении инвестиций, гарантируя достижение максимального возврата на инвестиции

$\rightarrow \quad$ Инвестиционная деятельность является наиболее целесообразной в момент окончательной зрелости компании, когда технологии не требуют ремонта и замены, а продукция широко распространена и имеет постоянные точки сбыта и реализации [14].

К основным результатам проведенного исследования можно отнести:

- дано авторское определение, которое наиболее полно отражает специфику термина инвестиции.

- был проведен сравнительный анализ ведения инвестиционной деятельности на нефтеперерабатывающих предприятиях ПАО «ЛУКОЙЛ» и ПАО «ГАЗПРОМНЕФТЬ», вследствие чего, авторами были сделаны следующие выводы [15]:

$\rightarrow \quad$ любое НПП имеет своей целью расширение территории добычи нефти;

$\rightarrow \quad$ любое НПП имеет острую необходимость привлечения инвестиций;

$\rightarrow$ на этапе жизненного цикла НПП «зрелость» привлечение инвестиций является наиболее целесообразным 
Кроме того, вследствие произведённого исследования было установлено, что из-за падения цены на нефть инвестиционный бюджет претерпел существенные изменения, как видно из таблицы 4.

\section{Таблица капитальных затрат ПАО «Лукойл» $3 а 2015$ г. (млн. долларов США)}

\begin{tabular}{|c|c|c|c|c|}
\hline \multirow{3}{*}{$\begin{array}{c}\text { Капитальные затраты, } \\
\text { включая неденежные } \\
\text { операции и авансовые } \\
\text { платежи }\end{array}$} & \multicolumn{2}{|c|}{ 3-й квартал 2015} & \multicolumn{2}{|c|}{9 месяцев 2015} \\
\hline & 2014 & 2013 & 2014 & 2013 \\
\hline & \multicolumn{4}{|c|}{ (млн. долларов США) } \\
\hline \multicolumn{5}{|l|}{ Разведка и добыча } \\
\hline Россия & 2094 & 1947 & 6534 & 5866 \\
\hline за рубежом & 906 & 841 & 2636 & 2377 \\
\hline Итого разведка и добыча & 3000 & 2788 & 9170 & 8243 \\
\hline \multicolumn{5}{|l|}{ Переработка, торговля и сбыт } \\
\hline Россия & 551 & 487 & 1459 & 1281 \\
\hline за рубежом & 193 & 279 & 624 & 604 \\
\hline $\begin{array}{l}\text { Итого переработка, торговля и } \\
\text { сбыт }\end{array}$ & 744 & 766 & 2083 & 1885 \\
\hline \multicolumn{5}{|l|}{ Нефтехимия } \\
\hline Россия & 88 & 18 & 168 & 52 \\
\hline за рубежом & 1 & 1 & 1 & 2 \\
\hline Итого нефтехимия & 89 & 19 & 169 & 54 \\
\hline Энергетика & 62 & 86 & 140 & 201 \\
\hline Прочие & 63 & 96 & 118 & 345 \\
\hline Итого капитальных затрат & 3958 & 3755 & 11680 & 10728 \\
\hline
\end{tabular}

Источник: составлено автором.

\section{Заключение}

Целесообразность вложения средств в НПП РФ заключается в том, что такие предприятия как ПАО «Лукойл» и ПАО «Газпромнефть» имеют долгосрочный план развития, учитывающий возможные изменения во внутренних и внешних условиях, проявившие себя как предприятия, умеющие быстро реагировать и адаптироваться к происходящим изменениям. Вложение средств в такие компании будет способствовать дальнейшему развитию нефтяной отрасли в РФ, как одной из ведущих отраслей экономики России, что обеспечит сохранение конкурентных позиций страны на международной арене, $\mathrm{a}$, соответственно, благотворно повлияет на получение прибыли от произведенных инвесторами вложений.

\section{Примечания:}

1. Шарп У.Ф., Бэйли Д.В. Инвестиции: [учеб.] для студентов вузов, обучающихся по экон. специальностям. М.: ИНФРА-М, 2013. XII, 1028 с.

2. "Об инвестиционной деятельности в Российской Федерации, осуществляемой в форме капитальных вложений". Федеральный закон от 25.02.1999 N 39-Ф3 (ред. от 28.12.2013) // М.: Справочно-правовая система «КонсультантПлюс». 
3. Хазанович Э.С., Ажлуни А.М., Моисеев А.В. Инвестиционная стратегия: учеб. пособие для студентов, обучающихся по специальностям "Финансы и кредит", "Мировая экономика". М.: КноРус, 2010. 304 с.

4. Инвестиционная стратегия предприятия: учебное пособие / Н. И. Лахметкина. M: KHOPУC, 2006-184c. ISBN5-85971-295-2

5. Монография «Инвестиции и инновации в экономике России и регионов» Ю.А. Корчагин, В.Н. Логунов, Воронеж: ЦИРЭ, 2008 с. 230

6. Инвестиционные стратегии: учебное пособие для студентов специальности 08010565 «Финансы и кредит» и направления 080100.62 «Экономика» / Н. В. Ширяева, А.В. Пострелова. Ульяновск: УлГТУ, 2012. 138 с.

7. Экономический анализ реальных инвестиций: учебник / И.В. Липсиц, В.В. Кокосов. 3-е издание, перераб. и доп. М.: Магистр, 2010. 384 с.

8. Бланк И.А. Энциклопедия финансового менеджера [В 4 томах]. Том 3. Управление инвестициями предприятия. 2-е изд., стер. М.: Издательство «Омега-Л, 2008. $480 \mathrm{c.}$

9. Брусов П. Н., Филатова Т. В., Лахметкина Н. Инвестиционный менеджмент: Учебник. М. ИНФРА-М, 2014. 333 с.

10. Некрасов А.С. Анализ и прогнозы развития отраслей топливно-энергетического комплекса. ИНП РАН, Москва, 2013. 250 с.

11. Аллард Ван Рил. Повышение эффективности принятия решений за счет концентрации внимания на этапе отбора имеющихся предложений с использованием высокотехнологичных сервисов // Журнал "Управленческие решения", номер 5, 2011. $762-783 \mathrm{c}$.

12. Колмыкова Т.С. Инвестиционный анализ: учеб. пособие для студентов вузов, обучающихся по специальности "Бухгалт. учет, анализ и аудит". М.: ИНФРА-М, 2011. 204 с.

13. Аллард Ван Рил, Трофимов О.В., Наконечный Н.И., Новикова Д.С. Особенности отбора инвестиционных проектов с использованием матрицы оценки рисков // Вестник ННГУ им. Н.И. Лобачевского. Серия: Экономические науки. 2016 г. № 1. С. 180-191.

14. Татаринцева С.Г., Епрынцева Е.С. Анализ показателей оценки эффективности формирования и реализации инвестиционной политики компаний нефтегазового сектора экономики РФ // Вестник КГУ им. Н.А. Некрасова. 2014. № 3 (63). С. 104-108.

15. Данилина М.В., Ерошкин С.Ю. Анализ топливно-энергетического комплекса России.

\section{References:}

1. Sharp U.F., Beili D.V. Investitsii: [ucheb.] dlya studentov vuzov, obuchayushchikhsya po ekon. spetsial'nostyam. M.: INFRA-M, 2013. XII, $1028 \mathrm{~s}$.

2. $\quad$ "Ob investitsionnoi deyatel'nosti v Rossiiskoi Federatsii, osushchestvlyaemoi v forme kapital'nykh vlozhenii". Federal'nyi zakon ot 25.02.1999 N 39-FZ (red. ot 28.12.2013) // M.: Spravochno-pravovaya sistema «Konsul'tantPlyus».

3. Khazanovich E.S., Azhluni A.M., Moiseev A.V. Investitsionnaya strategiya: ucheb. posobie dlya studentov, obuchayushchikhsya po spetsial'nostyam "Finansy i kredit", "Mirovaya ekonomika". M.: KnoRus, 2010. 304 s.

4. Investitsionnaya strategiya predpriyatiya: uchebnoe posobie / N. I. Lakhmetkina. M: KNORUS, 2006-184s. ISBN5-85971-295-2

5. Monografiya «Investitsii i innovatsii v ekonomike Rossii i regionov» Yu.A. Korchagin, V.N. Logunov, Voronezh: TsIRE, 2008 s. 230

6. Investitsionnye strategii: uchebnoe posobie dlya studentov spetsial'nosti 08010565 «Finansy i kredit» i napravleniya 080100.62 «Ekonomika» / N. V. Shiryaeva, A. V. Postrelova. Ul'yanovsk: UlGTU, 2012. $138 \mathrm{~s}$.

7. Ekonomicheskii analiz real'nykh investitsii: uchebnik / I. V. Lipsits, V. V. Kokosov. 3-e izdanie, pererab. i dop. M.: Magistr, 2010. $384 \mathrm{~s}$.

8. Blank I.A. Entsiklopediya finansovogo menedzhera [V 4 tomakh]. Tom 3. Upravlenie investitsiyami predpriyatiya. 2-e izd., ster. M.: Izdatel'stvo «Omega-L, 2008. $480 \mathrm{~s}$.

9. Brusov P. N., Filatova T. V., Lakhmetkina N. Investitsionnyi menedzhment: Uchebnik. M. INFRA-M, 2014. 333 s. 
10. Nekrasov A.C. Analiz i prognozy razvitiya otraslei toplivno-energeticheskogo kompleksa. INP RAN, Moskva, 2013. 250 s.

11. Allard Van Ril. Povyshenie effektivnosti prinyatiya reshenii za schet kontsentratsii vnimaniya na etape otbora imeyushchikhsya predlozhenii s ispol'zovaniem vysokotekhnologichnykh servisov // Zhurnal "Upravlencheskie resheniya", nomer 5, 2011. 762-783 s.

12. Kolmykova T.S. Investitsionnyi analiz: ucheb. posobie dlya studentov vuzov, obuchayushchikhsya po spetsial'nosti "Bukhgalt. uchet, analiz i audit". M.: INFRA-M, 2011. 204 s.

13. Allard Van Ril, Trofimov O.V., Nakonechnyi N.I., Novikova D.S. Osobennosti otbora investitsionnykh proektov $\mathrm{s}$ ispol'zovaniem matritsy otsenki riskov // Vestnik NNGU im. N.I. Lobachevskogo. Seriya: Ekonomicheskie nauki. 2016 g. № 1. S. 180-191.

14. Tatarintseva S.G., Epryntseva E.S. Analiz pokazatelei otsenki effektivnosti formirovaniya i realizatsii investitsionnoi politiki kompanii neftegazovogo sektora ekonomiki RF // Vestnik KGU im. N.A. Nekrasova. 2014. № 3 (63). S. 104-108.

15. Danilina M.V., Eroshkin S.Yu. Analiz toplivno-energeticheskogo kompleksa Rossii.

УДК 33

\section{Сравнительный анализ ведения инвестиционной деятельности на нефтеперерабатывающих предприятиях в РФ (на примере ОАО «ЛУКОЙЛ» и ОАО «ГАЗПРОМ-НПЗ»)}

${ }^{1}$ O.В. Трофимов

2 Д.С. Новикова

3 А.Д. Новикова

1-3 ИЭП ННГУ им. Н.И. Лобачевского, Российская Федерация

${ }^{1}$ Доктор экономических наук, профессор

${ }^{2}$ Ассистент

3 Лаборант-исследователь

Аннотация. Данная статья посвящена исследованию вопроса специфики управления инвестиционной деятельностью на нефтеперерабатывающем предприятии в РФ. Целью данной статьи является дать сравнительный анализ ведения инвестиционной деятельности на нефтеперерабатывающих предприятиях. Для достижения поставленной цели в статье будут решаться следующие задачи:

1. изучить академическое определение термина инвестиции, затем на основе изученного материала и проведенного сравнительного анализа, предложить своё определение данного термина;

2. привести примеры инвестиционной деятельности нескольких нефтеперерабатывающих предприятий, а именно ПАО «ЛУКОЙЛ» и ПАО «ГАЗПРОМНПЗ»;

3. проанализировать статистические данные работы нефтеперерабатывающих предприятий и обосновать целесообразность ведения инвестиционной деятельности на нефтеперерабатывающем предприятии.

Ключевые слова: инвестиции, инвестиционная деятельность, управление инвестиционной деятельностью на нефтеперерабатывающем предприятии. 